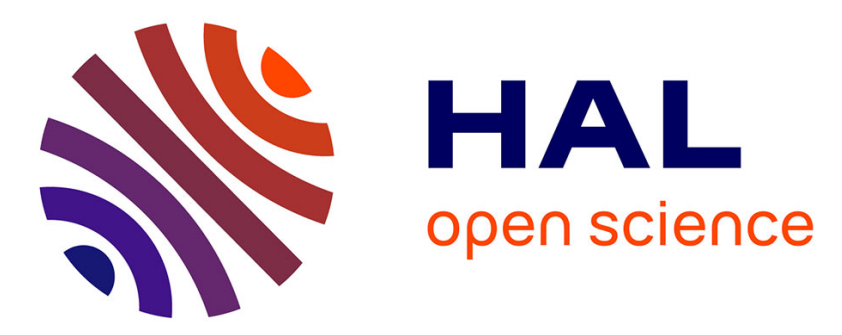

\title{
RIP and the shift toward a monetary union: Looking for a "euro effect" by a structural break analysis with panel data
}

Samuel Maveyraud-Tricoire, Philippe Rous

\section{- To cite this version:}

Samuel Maveyraud-Tricoire, Philippe Rous. RIP and the shift toward a monetary union: Looking for a "euro effect" by a structural break analysis with panel data. Journal of International Financial Markets, Institutions and Money, 2009, 19 (2), pp.336 - 350. 10.1016/j.intfin.2008.01.005 . hal01098936

\section{HAL Id: hal-01098936 \\ https://hal.science/hal-01098936}

Submitted on 30 Dec 2014

HAL is a multi-disciplinary open access archive for the deposit and dissemination of scientific research documents, whether they are published or not. The documents may come from teaching and research institutions in France or abroad, or from public or private research centers.
L'archive ouverte pluridisciplinaire $\mathbf{H A L}$, est destinée au dépôt et à la diffusion de documents scientifiques de niveau recherche, publiés ou non, émanant des établissements d'enseignement et de recherche français ou étrangers, des laboratoires publics ou privés. 


\title{
RIP and the shift toward a monetary union: looking for a "euro effect" by a structural break analysis with panel data
}

\author{
Samuel Maveyraud-Tricoire ${ }^{a}$, Philippe Rous ${ }^{b}$ \\ ${ }^{a}$ GRETHA, University of Bordeaux IV \\ ${ }^{\mathrm{b}} \mathrm{LAPE}$, University of Limoges
}

This version: 24 January 2008

\begin{abstract}
This paper aims to evaluate how the ex ante real interest rates of Euro area countries have been modified by the introduction of the euro. We use cointegration analysis with endogenous breaks in a panel data context. Our results show that the "euro effect" is significant in our sample and that after the introduction of the euro, the real interest parity (RIP) holds. This last conclusion is due to a decrease in the nominal interest rate differentials rather than to a reduction in goods and services price differentials and in the exchange rate volatility.
\end{abstract}

JEL classification: E43 ; F31 ; F36

Keywords: RIP; European integration; Panel data

* Corresponding author. Tel.: +33 5568485 87; fax: +33 555149215 .

E-mail addresses: samuel.maveyraud@u-bordeaux4.fr (S. Maveyraud-Tricoire), philippe.rous@unilim.fr (P. Rous).

\section{Introduction}

The switch from a multiple currencies regime to a monetary union modifies the conditions of the realisation of the real interest parity (hereafter RIP) between countries of this area. Indeed, as the adjustment associated with the exchange rates is not perfect (exchange rates are volatile and therefore may increase uncertainty), the suppression of a multiple currencies regime implies that comparisons between domestic and foreign interest rates and between the prices of domestic and foreign goods and services are made easier. Thus, the adoption of a common currency should deepen integration between countries of the monetary union. 
However, the increase of both financial and economic competition, following the suppression of exchange rate premia and uncertainty associated with exchange rate volatility, does not necessarily promote the convergence of real interest rates as the Optimum Currency Area (OCA) theory suggests (Frankel and Rose, 1998). Indeed, the deepening of competition, by supplying better opportunities that take advantage of economies of scale, may promote geographic concentration of industries and may therefore increase divergence in business cycles between countries of a monetary union (Krugman, 1993; Krugman and Venables, 1996). If so, the real interest rates between countries of a monetary union tend to diverge from one another.

In this paper, we propose to assess whether or not a shift toward a common currency regime has increased the convergence of the ex ante real interest rates of euro countries (i.e., the European Monetary Union (EMU) countries which have adopted the euro). The method used in this article consists of testing the stationarity of real interest rate differentials with endogenous multiple breaks based on the work of Carrion-i-Silvestre et al. (2005). When these differentials are stationary with no significant intercepts and trends after the introduction of the euro, we can conclude that the RIP holds as arbitrage options are exhausted between euro countries. Moreover, we apply this method to the uncovered interest parity (hereafter UIP) and to the relative purchasing power parity (hereafter PPP). As in Cheung et al. (2003), it will enable us to appraise how the financial and the real integration have been respectively modified by the introduction of the euro. And, since the sufficient condition for the RIP to hold is that both the UIP and the PPP prevail, we will strengthen the results obtained by the analysis of RIP. A further analysis appraises the evolution of the weight of UIP and exchange rate to explain deviations from RIP.

This article proceeds as follows. In the next section, we describe our data. Section 3 deals with the specificity of RIP test strategies, and Section 4 deals with RIP in a monetary union. 
Section 5 is devoted to the method we use for testing the RIP with endogenous breaks, while Section 6 presents the results. Section 7 concludes.

\section{Data}

We work with monthly data from Datastream International and the Central Bank of Portugal (See Appendix A for a detailed description of data). The considered series are the three-month interbank offered rates (hereafter IBOR 3-month) and the consumer price indexes for Austria (AUS), Belgium (BEL), Finland (FIN), France (FRA), Germany (GER), Ireland (IRE), Italy (ITA), Netherlands (NET), Portugal (POR) and Spain (SPA) ${ }^{1}$. The exchange rates for each pair of countries are also taken into account. In order to work with a balanced panel, the considered period is 1994M1-2005M12. The series are seasonally adjusted by using a multiplicative moving average method.

We constitute all the possible single pairs of countries (i.e., 45 pairs $=N(N-1) / 2$ ). With regard to the results, we focus our analysis for each where Germany is the partner country since it has played a key role in the introduction of the euro (cf., De Grauwe, 1997; and Holmes, 2002).

The considered period starts on the 1st November 1993, when the Treaty of Maastricht on European Union took effect. The Treaty aims to establish an economic and monetary union. Three successive events set the stage for the establishment of a single currency. The first, which liberalised capital movements, began the $1^{\text {st }}$ of January 1990 . The second stage began the $1^{\text {st }}$ of January 1994 and provided for convergence of the Member States' economic policies. The third started the $1^{\text {st }}$ of January 1999 with the creation of a single currency and the establishment of the European Central Bank.

\footnotetext{
${ }^{1}$ Luxembourg and Greece are not included in our sample. The reason for the exclusion of Luxembourg is the absence of the IBOR 3-month in our database. Greece has been excluded because, as the euro was only introduced at the beginning of 2002, its convergence process occured later than for the other euro countries.
} 
These events have two effects on ex ante real interest rate differentials. We observe on a diminution of the risk premium (in our model $\alpha_{i}$ ) and a process of convergence toward 0 of ex ante real interest rate differentials (in our model $\beta_{i}$ must be significant before the introduction of the euro and equal to 0 after).

Ex ante real interest rates are obtained for each country by subtracting the expected inflation rate (estimated using an $\mathrm{AR}(1)$ model $^{2}$ ) from the nominal interest rate. For testing the UIP (PPP), we subtract from nominal interest rate differentials (expected inflation rate differentials) the variation rate of the expected exchange rate (estimated using an $\mathrm{AR}(1)$ $\left.\operatorname{approach}^{3}\right)$.

The Hadri Z-stat indicates that we strongly reject the null hypothesis H0, that is that at least one pair of real interest rate differentials has a unit root (cf. Table 1). The individual LM statistics confirm this result as $\mathrm{H} 0$ is rejected at a $5 \%$ level of significance, for the great majority of the differentials except for some differentials of historical countries of the European Economic Community (Germany and Belgium, France and Belgium, France and Netherlands and Belgium and Finland).

[Table 1 about here]

\section{RIP test strategies}

\footnotetext{
${ }^{2}$ Several measures might have been taken into account for measuring expected inflation as Baharumshah et al. (2005), Baxter (1994) and Larsen, May and Talbot (2003) suggest it. These procedures are: 1) to use surveybased measures of inflation expectations, 2) to use econometric models to provide estimates of expected inflation, 3) to obtain an inflation forecast from an estimated time series model, such an ARMA model, or 4) to compute the exponential smoothing or moving average of the actual inflation series. In this article, we use the AR(1) model to measure the expected inflation rate. This method may not be the optimal one for calculating the expected inflation rate. However, it is applied in our study as it has been the main method used in recent papers estimating the expected inflation rate (cf., Holmes and Maghrebi, 2006; Baharumshah et al., 2005; Larsen, May and Talbot, 2003; and Baxter 1994 ).

${ }^{3}$ More precisely, the variation rate of the expected exchange rate of a pair of countries is the log of the difference between the expected exchange rate and the actual exchange rate of this pair. The expected inflation rate of the considered country is calculated as the log of the difference between the expected CPI and the actual CPI of this country.
} 
Two methods are used for testing RIP. The first one uses OLS regression (cf., inter alia, Mishkin, 1984; Mark, 1985; and Cumby and Mishkin, 1986) ${ }^{4}$ :

$$
E_{t} r_{t, t+k}=\alpha+\beta E_{t} r_{t, t+k}^{*}+\varepsilon_{t}
$$

In the equation (1), RIP prevails when the hypotheses $\alpha=0$ and $\beta=1$ cannot be rejected.

The problem arising from this method is that, except in a few cases (cf., inter alia, Fujii and Chinn, 2001), the ex ante (and ex post) real interest rates appear to be nonstationary. Consequently, the more recent studies use cointegration analysis when real interest rates are I(1) by imposing the restriction $(\alpha=0$ and $\beta=1)$ on the long-run relationship such that equation (1) can be rewritten as:

$$
E_{t} r_{t, t+k}-E_{t} r_{t, t+k}^{*}=\varepsilon_{t}
$$

If the residuals of equation (2) are stationary, then the real interest rates are cointegrated: the RIP holds. Contrasting results are obtained. The first method, which assumes the stationarity of real interest rates, rejects RIP most of the time. However, tests which used the second method, have found more support for the RIP (cf., inter alia, Modjtahedi, 1988).

Most of the studies on RIP are based on time series data, which is not robust for unit root testing. To resolve this problem, recent analyses test RIP by using panel data (cf., inter alia, Wu and Chen, 1998; Baharumshah et al., 2005). Results do not appear to be different from those obtained with time series, as real interest rate differentials are not systematically stationary.

Another weakness linked to the use of time series and panel data in the study of RIP is the possible presence of structural breaks. It is well known that such a feature may induce a fallacious lack of long-run relation between the variables. To solve this problem, Holmes (2002) takes into account the presence of structural breaks and truncates a sample of

\footnotetext{
${ }^{4}$ Studies use ex ante and/or ex post real interest rates. Here, we present the case where ex ante real interest rates are considered. Thus, we can neglect the unbiasedness hypothesis (i.e., the rational expectations) (cf., Frankel, 1982).
} 
European Union countries between the dates of 1979-1998 into 4 subperiods. However, the weak point of such a study is that breaks are exogenously determined. This article proposes to determine breaks endogenously in the RIP relationship and then perform a cointegration analysis in a panel data context for a sample of euro countries.

\section{RIP, economic integration and monetary union}

Based on arbitrage forces in financial and goods and services markets, the ex ante real interest parity implies the equality of domestic and foreign expected real interest rates:

$$
E_{t} r_{t, t+k}=E_{t} r_{t, t+k}^{*}
$$

where $r_{t, t+k}$ and $r_{t, t+k}^{*}$ are the domestic and the foreign real interest rate, respectively at date $\mathrm{t}$ for an asset of maturity $\mathrm{t}+\mathrm{k}$ and $E_{t}$ represents the expectations at date $\mathrm{t}$ for a date $\mathrm{t}+\mathrm{k}$. From the Fisher's equation (i.e., $E_{t} r_{t, t+k}=i_{t, t+k}-E_{t} \pi_{t, t+k}$ ), equation (3) can be rewritten as follows (cf., Frankel and MacArthur, 1988):

$$
\begin{aligned}
E_{t} r_{t, t+k}-E_{t} r_{t, t+k}^{*} & =i_{t, t+k}-i_{t, t+k}^{*}-\left(f_{t}^{t+k}-s_{t}\right)+f_{t}^{t+k}-E_{t} s_{t+k} \\
& +\left(E_{t} s_{t+k}-s_{t}\right)-E_{t} \pi_{t, t+k}+E_{t} \pi_{t, t+k}^{*}
\end{aligned}
$$

where $i_{t, t+k}$ and $i_{t, t+k}^{*}$ are the domestic and the foreign nominal interest rates, respectively, at

date $t$ for an asset of maturity $t+k, f_{t}^{t+k}$ is the forward discount rate at time $t$ expressed in $\log$ for delivery and payment at date $t+k, s_{t}$ is the direct quotation of the nominal exchange rate (i.e., the number of domestic currency units for one unit of foreign currency) expressed in $\log$, and $E_{t} \pi_{t, t+k}$ and $E_{t} \pi_{t, t+k}^{*}$ are the expected inflation rate of the domestic and the foreign consumer price levels expressed in logarithms, respectively, between dates $t$ and $t+k$

Following equation (4), a differential between ex ante real interest rates is due to: (1) the lack of financial market integration when the covered interest parity is not verified and the implication of frictions from capital controls, (2) the inefficiency of financial markets from 
imperfect information and/or incorrect expectations when the forward discount rate is not a perfect predicator of the expected exchange rate, and (3) the lack of integration of the goods and services markets when the relative purchasing power parity does not hold. These deviations are mainly explained by weak mobility and substitutability of inputs, home bias in consumption, pricing to market, untraded goods and variations in transaction costs.

After 1999, the introduction of the euro has simplified conditions for the realisation of the RIP between euro countries. Indeed, the efficiency of financial markets is no longer the issue and RIP can be decomposed as:

$$
E_{t} r_{t, t+k}-E_{t} r_{t, t+k}^{*}=i_{t, t+k}-i_{t, t+k}^{*}-E_{t} \pi_{t, t+k}+E_{t} \pi_{t, t+k}^{*}
$$

In this context, the RIP between euro countries only measures the degree of financial and real integration and not financial market inefficiencies.

\section{Method}

For testing the stationarity of ex ante real interest rate differentials, we implement the method of Carrion-i-Silvestre et al. (2005):

$$
E R D_{i, t}=\alpha_{i}+\beta_{i} t+\sum_{i=1}^{m_{i}} \vartheta_{i, l} D U_{i, l, t}+\sum_{i=1}^{m_{i}} \gamma_{i, l} D T_{i, t}+\varepsilon_{i, t}
$$

where $E R D_{i, t}$ is the expected real interest rate differentials for the pair i of countries. $D U_{i, l, t}$ is a dummy variable which takes the value 1 when $t \geq T_{l}^{i}$, (where $T_{l}^{i}$ denotes the $1^{\text {th }}$ break date for the $\mathrm{i}^{\text {th }}$ country pair, with $l=1, \ldots, m_{i}$ and $m_{i} \geq 1$ ), and 0 otherwise. The variable $D T_{i, t}$ is equal to $t-T_{l}^{i}$ for $t \geq T_{l}^{i}$ and 0 elsewhere. Note that the constant $\alpha_{i}$, the trend $\beta_{i}$ and the breaks coefficients $\left(\vartheta_{i, l}, \gamma_{i, l}\right)$ may be specific to each ex ante real interest rate differential.

Under the null hypothesis of a stationary panel with multiple shifts, the test statistic $Z(\lambda)$ follows the standard Gaussian law:

$$
Z(\lambda)=\left(\frac{\sqrt{N}(L M(\lambda)-\bar{\xi})}{\bar{\varsigma}}\right) \rightarrow N(0,1)
$$


with $\bar{\xi}=\frac{1}{N} \sum_{i=1}^{N} A \sum_{k=1}^{m_{i}+1}\left(\lambda_{i, l}-\lambda_{i, l-1}\right)^{2} \quad$ and $\quad \bar{\zeta}=\frac{1}{N} \sum_{i=1}^{N} B \sum_{k=1}^{m_{i}+1}\left(\lambda_{i, l}-\lambda_{i, l-1}\right)^{4} \quad$ where $\lambda_{i}=\left(\lambda_{i, 1}, \ldots, \lambda_{i, m_{i}}\right)^{\prime}=\left(\frac{T_{1}^{i}}{T}, \ldots, \frac{T_{m_{i}}^{i}}{T}\right)^{\prime}, \lambda_{i, 0}=0, \lambda_{i, m_{i}+1}=1$

$A=1 / 6$ and $B=1 / 45$ for $\beta_{i}=\gamma_{i, k}=0$ and $A=1 / 15$ and $B=11 / 6300$ for $\beta_{i} \neq$ $\gamma_{i, k} \neq 0$

The Lagrange multiplier is equal to:

$$
\operatorname{LM}(\lambda)=N^{-1} \sum_{i=1}^{N} \widehat{\omega}_{i}^{-2} T^{-2} \sum_{t=1}^{T} \hat{S}_{i, t}^{2}
$$

where $\widehat{\omega}_{i}^{-2}$ is the consistent estimate of the long-run variance of the error term $\varepsilon_{i, t}$, and $\hat{S}_{i, t}^{2}=\sum_{j=1}^{t} \hat{\varepsilon}_{i j}$ represents the partial sum process of the estimated ordinary least squared (OLS) residuals. The LM stat depends on the number and on the localisation of breaks as denoted by $\lambda$.

We proceed as follows. First, we test if the differentials of ex ante real interest rates are stationary by applying the Hadri Z-test and individual Kwiatkowski-Phillips-Schmidt-Shin (KPSS) tests. If we reject the null hypothesis that there is at least one ex ante real interest rate differential which has a unit root, then we must introduce breaks as in equation (6) and test the stationarity of ex ante real interest rate differentials again. Then, as the RIP can be decomposed into UIP and PPP, we test if the differentials associated with these relationships are stationary.

\section{Results}

As can be seen from the results, the RIP does not seem to prevail in the euro area, except for a few country pairs. Thus, we introduce breaks into the equation. For detecting breaks, which can be located at different dates for each country, we apply the method proposed by Bai and Perron $(1998,2003)^{5}$. The maximum number of break points $\left(m^{\max }\right)$ is equal to 3 .

\footnotetext{
${ }^{5}$ For a discussion on the methods used for detecting breaks see Carrion-i-Silvestre et al., 2005.
} 
Given $m^{\max }$, the detection of breaks consists of estimating their position for each $m_{i} \leq$ $m^{\max }, \mathrm{i}=1,2,3$. Then we test the significance of the breaks by computing the global minimum of the SSR. We identify the optimal number of breaks and their location through a LM test strategy. First, using a LR test, we compare the likelihood of the "best" 1 break (min SSR criterion) and the no break model with an amount of trimming specified as $T_{i} \in$ $[0.10 T, 0.90 T]$. If the null is rejected, then we compare the likelihoods of the "best" 2 breaks model with the "best" 1 break model, and so on. ${ }^{6}$

The results show that we cannot reject the null associated with the Hadri Z-stat at a 5\% level: the ex ante real interest differentials are stationary, at least around a constant and a trend, for each pair of countries after accounting for the breaks (cf. table 2).

[Table 2 about here]

Differentials of ex ante real interest rates have two breaks at the minimum and in most of the cases, three breaks. They are located between 1995M1 and 1997M8 for the first two breaks and between 1997M4 and 1999M4 for the last one. Table 3 presents the results associated with the real interest rate differentials between Germany and the other countries of the euro area. ${ }^{7}$

The first and the second breaks seem to be due to the rise of United States short-term interest rates. Between 1994 and 1995, the US three-month interbank rate increased from 3\% up to more than 5.5\% and probably had different impacts on European interest rates, so that real interest rate differentials between EMU countries tended to be disconnected. However, the last break may be associated with the arrival of the euro. Most of the time, the break

\footnotetext{
${ }^{6}$ In order to strengthen these results, we also use a Bayesian information criterion to detect endogenous breaks (Wang, 2006). The dates of the breaks are quite the same as those presented here.

${ }^{7}$ The whole of the differentials are available on request. The results are similar to those presented here.
} 
happened earlier for the "core" countries of the EEC (that is at the end of 1997). For the other countries, the break is located at the end of 1998. Two exceptions can be found: in Finland, where the break is located at the end of 1997, and in the Netherlands, where the break occurred at the beginning of 1999.

Before the last break, constants, which can be associated with the risk premium, are highly significant for most differentials, with a negative sign. Thus, as could be expected, the risk premium is in favour of the German expected real interest rate which can be up to 1000 basis points more compared to the Italian expected real interest rate. However, after the last break, the constant is not significant at the 5\% level. Risk premia have disappeared between real interest rates with the introduction of the euro.

Moreover, the trend is positive and highly significant between the second and the third break (between the first and the second break for the real interest rate differential between Germany and Portugal as there are only two breaks), which seems to indicate that the differentials converge to $0^{8}$. During the last period (after the last break), the trend is not significant at the $1 \%$ level. Therefore, we cannot reject the null hypothesis of stationarity of expected real interest rate. Moreover, both the constant and the trend are not significantly different from 0 for each expected real interest rate differential after the last break associated with the euro effect. Hence, this means that expected real interest rate differentials are not different from 0 with no trend. We may therefore state that after the last break expected real interest rate differentials are stationary around 0 and the RIP holds in the euro area.

[Table 3 about here]

\footnotetext{
${ }^{8}$ With this method, it is not possible to know if real interest rates of euro countries converge to the German real interest rate. However, we can assume it.
} 
We now try to check if the UIP and the PPP hold. There are two reasons for these tests. First, as we show in equation (2), a sufficient condition for the RIP to hold is that both the UIP and the PPP hold. Thus, we need to conduct these tests to strengthen the results obtained above. Moreover, UIP can be used as a measure of financial markets integration and PPP as a measure of goods and services markets integration. By using these measures, we will clarify how the integration of these markets has evolved before and after the introduction of the euro.

We test the stationarity of the nominal interest rate differentials and the expected inflation rate differentials net of the variation rates of the expected exchange rate (Table 4), by using the following regression:

$$
\begin{aligned}
& N D_{i, t}-E_{t} s_{i, t+k}=\alpha_{i}+\beta_{i} t+\sum_{i=1}^{m_{i}} \vartheta_{i, l} D U_{i, l, t}+\sum_{i=1}^{m_{i}} \gamma_{i, l} D T_{i, t}+\varepsilon_{i, t} \\
& E \Pi D_{i, t}-E_{t} s_{i, t+k}=\alpha_{i}^{\prime}+\beta_{i}^{\prime} t+\sum_{i=1}^{m{ }_{i}} \vartheta_{i, l}^{\prime} D U_{i, l, t}^{\prime}+\sum_{i=1}^{m^{\prime} i} \gamma_{i, l}^{\prime} D T^{\prime}{ }_{i, t}+\varepsilon_{i, t}^{\prime}
\end{aligned}
$$

where $N D_{i, t}$ and $E \Pi D_{i, t}$ are the nominal interest rate differentials and the ex ante inflation rate differentials for the pair of countries i. The Hadri Z-test with no breaks indicates that we strongly reject the null for both the UIP and the PPP tests. Once the breaks are taken into account, then, as for real interest rate differentials, we cannot reject the model with constant and trend the null at a 5\% level for the UIP test and at a 1\% level for the PPP test.

[Table 4 about here]

Breaks, constants and trends in the UIP test are close to those obtained with ex ante real interest rate differentials (Table 5). Indeed, as for the analysis of ex ante real interest rate differentials, three significant breaks are detected except for the pair Germany-Portugal where we only retain two breaks. The last break seems to be associated with the beginning of the period of the euro. For ex ante real interest rate differentials, constants and trends are not 
significant after the last break. Thus, we can conclude that the UIP prevailed between euro countries after the introduction of the euro.

[Table 5 about here]

The results are different for the PPP test (Table 6). Indeed, most countries have only one or two breaks and for the pair Germany-Netherlands, where no breaks are significant. Also, since the end of 1996, except for the pair Germany-Finland and Germany-Ireland, constants and trends are not significant. Therefore the introduction of the euro has a moderate effect on goods and services price convergence. And thus, according to these results, the PPP prevails more than 2 years before the euro.

[Table 6 about here]

This study shows that both financial and real integration prevail between euro countries after the introduction of the euro. With regard to the financial integration, the putting in place of the euro has deepened arbitrage operations, so that the UIP could be verified. However, for most countries, the real integration prevailed several years before the euro. These results are in line with previous research on this subject. In particular, Koedijk et al. (2004) present evidence in favor of relative PPP within the euro area over the period 1973-2003 when individual heterogeneity is taken into account. Interestingly, as in our study, they find that "neither the Maastricht Treaty nor the introduction of the euro has a reliable effect on the test [of PPP]". Moreover, Gikas et al. (2006) find that bond yields and inflation rates converge in the euro area in the 1990s and that this convergence leads to full integration. 
These tests raise the question of the evolution of the weight of each component in the explanation of the deviations from RIP. In particular, we ask whether the variations of the exchange rate may explain significant differentials that prevail before the introduction of the euro. To this end, for each pair of countries, the correlations of nominal interest differentials and expected exchange rates with real interest differentials are considered.

[Table 7 about here]

The nominal interest rate differentials are highly (and positively) correlated with the differentials of the ex ante real interest rate. The introduction of the euro plays a minor role because even if the coefficients tend to decrease after the last break, they remain relatively high. The expected exchange variation rates cannot explain the diminution of ex ante real interest rate differentials. In most cases, correlation coefficients are close to 0 after the first period (Table 7).

\section{Conclusion}

We have used European data on interest rates, inflation rates and exchange rates to appraise in what extent the real interest rates of European countries have converged with the introduction of the euro. Cointegration techniques with panel data show that the creation of the euro has an impact on the RIP of European countries. More precisely, the establishment of a monetary union has encouraged the convergence of countries belonging to the monetary area as the endogenous optimum currency area theory suggested it would. Indeed, after the last break, which can be attributed to the euro effect, the RIP holds. Moreover, the creation of the euro seems to have a stronger impact on financial integration (UIP holds after the establishment of the euro for each differential) than on real integration (PPP holds for most 
pairs of countries a few years before the introduction of the euro). Lastly, the euro effect cannot be directly associated with the end of European currencies but more with the convergence of money markets. This empirical study needs a more general application in order to test the link between exchange rate regime and integration as measured by RIP.

\section{Acknowledgment}

The authors would like to thank two anonymous referees. The usual disclaimer applies.

\section{Appendix A: Datastream codes}

The datastream codes are given in table 8 .

[Table 8 about here]

\section{References}

Baharumshah, A.Z., Haw, C.T., Fountas, S., 2005. A panel study on real interest rate parity in East Asian countries: pre- and post-liberalization era. Global Finance Journal 16, 69-85.

Bai, J., Perron, P., 1998. Estimating and testing linear models with multiple structural changes. Econometrica 66, 47-78.

Bai, J., Perron, P., 2003. Computation and analysis of multiple structural change models. Journal of Applied Econometrics 18, 1-22.

Baxter, M., 1994. Real exchange rates and real interest differentials: have we missed the business cycle relationship? Journal of Monetary Economics 33, 5-37.

Carrion-i-Silvestre, J.L., del Barrio, T., López-Bazo, E., 2005. Breaking the panels: an application to GDP per capita. Econometrics Journal 8, 159-175.

Cheung, Y.-W., Chinn, M.D., Fujii, E., 2003. China, Hong Kong, and Taiwan: a quantitative assessment of real and financial integration. China Economic Review 4, 281-303. 
Cumby, R.E., Mishkin, F.S., 1986. The international linkage of real interest rates: the European-U.S. connection. Journal of International Money and Finance 5, 5-23.

De Grauwe, P., 1997. The Economics of Monetary Integration. Oxford University Press, Oxford.

Frankel, J.A., 1982. A technique for extracting a measure of expected inflation from the interest rate term structure. Review of Economics and Statistics 64, 135-141.

Frankel, J.A., MacArthur, A.T., 1988. Political vs. currency premia in international real interest differentials: a study of forward rates for 24 countries. European Economic Review 32, 1083-1114.

Frankel, J.A., Rose, A., 1998. The endogeneity of the optimum currency area criteria. Economic Journal 108, 1009-1026.

Fujii, E., Chinn, M., 2001. Fin de siecle real interest parity. Journal of International Financial Markets, Institutions and Money 11, 289-308.

Gikas, A.H., Malliaropulos, D., Priestley, R., 2006. EMU and European stock market integration identifiers. The Journal of Business 79, 365-392.

Hadri, K., 2000. Testing for stationarity in heterogeneous panel data. Econometrics Journal 3 (2), 148-161.

Holmes, M.J., 2002. Does long-run real interest parity hold among EU countries? Some new panel data evidence. The Quarterly Review of Economics and Finance 42, 733-746.

Holmes, M.J., Maghrebi, N., 2006. Are international real interest rate linkages characterized by asymmetric adjustments? Journal of International Financial Markets, Institutions and Money 16 (4), 384-396.

Koedijk, K.G., Tims, B., van Dijk, M. A., 2004. Purchasing power parity and the euro area. Journal of International Money and Finance 23, 1081-1107. 
Krugman, P., 1993. Lessons of Massachusetts for the EMU. In: Torres, F., Giavazzi, F., (Eds.), Adjustment and Growth in the European Monetary Union. Cambridge University Press, 241-260.

Krugman, P., Venables, A., 1996. Integration, specialisation and adjustment. European Economic Review 40, 959-967.

Kwiatkowski, D., Phillips, P.C.B., Schmidt, P., Shin, Y., 1992. Testing the null hypothesis of stationarity against the alternative of a unit root: how sure are we that economic time series have a unit root? Journal of Econometrics 54, 159-78.

Larsen, J., May, B., Talbot, J., 2003. Estimating real interest rates for the United Kingdom. Bank of England Working Paper 20.

Mark, N.C., 1985. Some evidence on the international inequality of real interest rates. Journal of International Money and Finance 4, 189-208.

Mishkin, F.S., 1984. Are real interest rates equal across countries? An empirical investigation of international parity conditions. Journal of Finance 39, 1345-1357.

Modjtahedi, B., 1988. Dynamics of real interest differentials: an empirical investigation. European Economic Review 32, 1191-1212.

Wang, Z., 2006. The joint determination of the number and the type of structural changes. Economics Letters 93, 222-227.

Wu, J.-L., Chen, S.-L., 1998. A re-examination of real interest rate parity. Canadian Journal of Economics 31, 837-851. 